\title{
Effects of tacrolimus on morphology, proliferation and differentiation of mesenchymal stem cells derived from gingiva tissue
}

\author{
DONG-HO HA ${ }^{1}$, CHUL SOON YONG ${ }^{1}$, JONG OH KIM ${ }^{1}$, JEE-HEON JEONG ${ }^{1}$ and JUN-BEOM PARK ${ }^{2}$ \\ ${ }^{1}$ College of Pharmacy, Yeungnam University, Gyeongsan-si, Gyeongsangbuk-do 38541; ${ }^{2}$ Department of Periodontics, \\ College of Medicine, The Catholic University of Korea, Seoul 06591, Republic of Korea
}

Received March 4, 2015; Accepted February 18, 2016

DOI: $10.3892 / \mathrm{mmr} .2016 .5217$

\begin{abstract}
Tacrolimus is a 23-membered macrolide lactone with potent immunosuppressive activity that is effective in the prophylaxis of organ rejection following kidney, heart and liver transplantation. Tacrolimus also exerts a variety of actions on bone metabolism. The aim of the present study was to evaluate the effects of different concentrations of tacrolimus on the morphology and viability of human stem cells derived from the gingiva. Gingival-derived stem cells were grown in the presence of tacrolimus at final concentrations ranging from 0.001 to $100 \mu \mathrm{g} / \mathrm{ml}$. The morphology of the cells was viewed under an inverted microscope and the cell viability was analyzed using Cell Counting kit-8 (CCK-8) on days 1, 3,5 and 7. Alizarin Red S staining was used to assess mineralization of treated cells. The control group showed spindle-shaped, fibroblast-like morphology and the shapes of the cells in 0.001 , $0.01,0.1,1$ and $10 \mu \mathrm{g} / \mathrm{ml}$ tacrolimus were similar to those of the control group. All groups except the $100 \mu \mathrm{g} / \mathrm{ml}$ group showed increased cell proliferation over time. Cultures grown in the presence of tacrolimus at $0.001,0.01,0.1,1$ and $10 \mu \mathrm{g} / \mathrm{ml}$ were not identified to be significantly different compared with the control at days 1, 3 and 5 using the CCK- 8 assays. Increased mineralized deposits were noted with increased incubation time. Treatment with tacrolimus from 0.001 to $1 \mu \mathrm{g} / \mathrm{ml} \mathrm{led}$ to an increase in mineralization compared with the control group. Within the limits of this study, tacrolimus at the tested concentrations (ranging from 0.001 to $10 \mu \mathrm{g} / \mathrm{ml}$ ) did not result
\end{abstract}

Correspondence to: Professor Jee-Heon Jeong, College of Pharmacy, Yeungnam University, 280 Daehak-Road, Gyeongsan-si, Gyeongsangbuk-do 38541, Republic of Korea

E-mail: jeeheon@yu.ac.kr

Dr Jun-Beom Park, Department of Periodontics, College of Medicine, The Catholic University of Korea, 222 Banpo-daero, Seocho-gu, Seoul 06591, Republic of Korea

E-mail: jbassoonis@yahoo.co.kr

Key words: cell differentiation, cell proliferation, cell survival, gingiva, stem cells, tacrolimus in differences in the viability of stem cells derived from gingiva; however it did enhance osteogenic differentiation of the stem cells.

\section{Introduction}

Mesenchymal stem cells (MSCs) are multipotent progenitor cells that have the capacity for self-renewal and differentiation into osteocytes, adipocytes and other cells (1). MSCs have been used in preclinical models for tissue engineering of bone, cartilage, muscle, marrow stroma, tendon, fat and other connective tissues (2-4). In addition, MSCs secrete a broad spectrum of bioactive macromolecules that are immunomodulatory and serve to structure regenerative microenvironments in fields of tissue injury (5). Human mesenchymal stem cells have previously been isolated and characterized from the gingiva, and gingiva-derived stem cells have been applied for tissue engineering purposes (6). Moreover, stem cells may be obtained intraorally, and gingiva is a readily accessible tissue source with a relatively high quantity of obtainable tissue (7).

Tacrolimus is a 23-member macrolide lactone (molecular weight, $803.5 \mathrm{Da}$ ) with potent immunosuppressive activity that is effective in the prophylaxis of organ rejection following liver, heart, kidney and small bowel transplantation (8). Tacrolimus has a narrow therapeutic window (9) and it is important to choose the right dose (10). Clinically, the doses of tacrolimus administered following kidney, heart and liver transplantation are 0.15-0.3,0.05-0.075 and 0.10-0.2 mg/kg/day, respectively (11-14). In addition, whole blood tacrolimus concentrations were observed to be $10-15 \mathrm{ng} / \mathrm{ml}$ during months $1-3$ and $5-12 \mathrm{ng} / \mathrm{ml}$ during months $4-12$ with the initial tacrolimus dose of $0.15-0.2 \mathrm{mg} / \mathrm{kg} /$ day $(14,15)$.

Tacrolimus has been shown to exert a variety of actions on bone metabolism (16). It was reported that tacrolimus causes bone loss when administered systemically $(17,18)$. However, other studies have shown that tacrolimus promotes osteogenic differentiation $(19,20)$. Conversely, another study demonstrated that tacrolimus was not associated with osteogenic differentiation of human heart-derived MSCs (21).

Limited information is currently available regarding the effects of tacrolimus on dental tissue, and none is available 

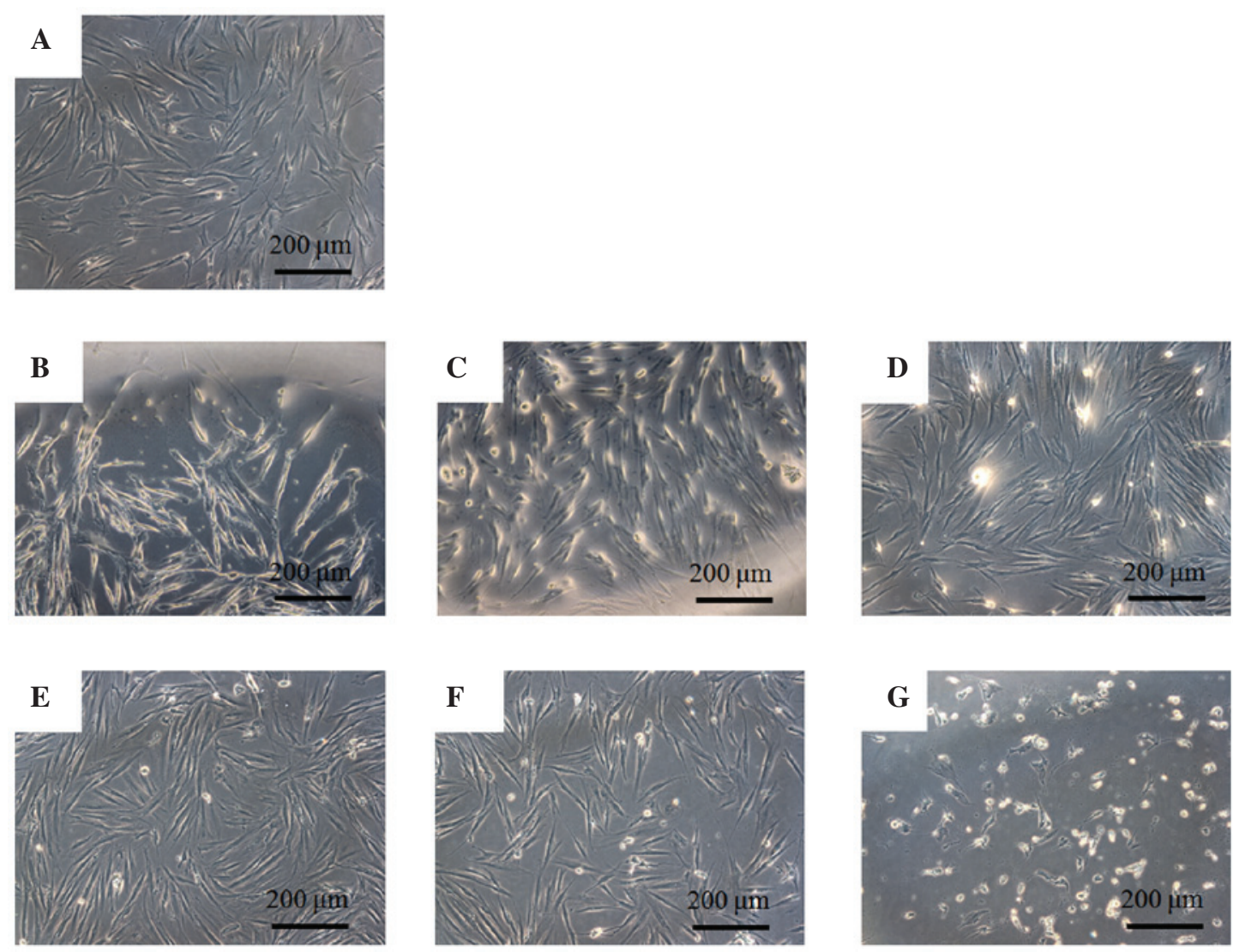

Figure 1. Evaluation of cell morphology on day 1 using inverted microscopy following treatment with tacrolimus of different concentrations. (A) Control, (B) $0.001 \mu \mathrm{g} / \mathrm{ml}$ group, (C) $0.01 \mu \mathrm{g} / \mathrm{ml}$ group, (D) $0.1 \mu \mathrm{g} / \mathrm{ml}$ group, (E) $1 \mu \mathrm{g} / \mathrm{ml}$ group, (F) $10 \mu \mathrm{g} / \mathrm{ml}$ group and (G) $100 \mu \mathrm{g} / \mathrm{ml}$ group.

on its effects on human mesenchymal stem cells derived from the gingiva. The aim of the present study was to evaluate the effects of a broad range of concentrations of tacrolimus on the morphology and viability of human stem cells derived from the gingiva.

\section{Materials and methods}

Isolation and culture of stem cells derived from the gingiva. Healthy gingival tissue samples were collected from healthy patients (mean age, 51.8 \pm 18.1 years; 2 male and 2 female) and this study was reviewed and approved by the Institutional Review Board of Seoul St. Mary's Hospital, College of Medicine, The Catholic University of Korea (Seoul, Korea; approval no. KC11SISI0348); informed consent was obtained from all patients. The resected gingival tissues were immediately placed in sterile phosphate-buffered saline (PBS; Welgene Inc., Daegu, Korea) with $100 \mathrm{U} / \mathrm{ml}$ penicillin and $100 \mu \mathrm{g} / \mathrm{ml}$ streptomycin (Sigma-Aldrich, St. Louis, MO, USA) at $4^{\circ} \mathrm{C}$. The gingival tissue was de-epithelialized, minced into $1-2 \mathrm{~mm}^{2}$ fragments, and digested in $0.2 \mu \mathrm{m}$ filtered $\alpha$-Minumum Essential Medium (MEM; HyClone; GE Healthcare Life Sciences, Chalfont, UK) with collagenase IV (Sigma-Aldrich). The cells were incubated at $37^{\circ} \mathrm{C}$ in a humidified incubator with $5 \% \mathrm{CO}_{2}$ and $95 \% \mathrm{O}_{2}$. After $24 \mathrm{~h}$, the non-adherent cells were washed with PBS, and adherent cell were administered fresh medium and replaced every 2-3 days. A previous report demonstrated that these cells showed colony-forming abilities, plastic adherence, and multilineage differentiation (osteogenic, adipogenic, chondrogenic) potency (22). The cells expressed CD44, CD73, CD90, and CD105, but did not express CD14, CD45, CD34, and CD19 in flow cytometry (22).

Evaluation of cellular morphology. The cells were plated at a density of $2.0 \times 10^{3}$ cells/well in 96-well plates. The cells were incubated in $\alpha$-MEM containing $15 \%$ fetal bovine serum (Gibco; Thermo Fisher Scientific Inc., Waltham, MA, USA), $100 \mathrm{U} / \mathrm{ml}$ penicillin and $100 \mu \mathrm{g} / \mathrm{ml}$ streptomycin in the presence of tacrolimus at final concentrations ranging of 0 (control), $0.001,0.01,0.1,1,10$ and $100 \mu \mathrm{g} / \mathrm{ml}$. Tacrolimus was dissolved in dimethyl sulfoxide (DMSO; Sigma-Aldrich) and filter-sterilized. Equal quantities of DMSO were added to each culture sample to offset the influence of this dissolving vehicle. The morphology of the cells was viewed under an inverted microscope (Leica DM IRM, Leica Microsystems, Wetzlar, Germany) on days 1,3, 5 and 7. The images were saved as JPEGs.

Determination of cell viability. The cell viability analysis was performed on days 1,3,5 and 7.2-(2-methoxy-4-nitrophe nyl)-3-(4-nitrophenyl)-5-(2,4-disulfophenyl)-2H tetrazolium, monosodium salt (WST-8 from Cell Counting kit-8; Dojindo, Tokyo, Japan) was added to the culture and the cells were incubated for $3 \mathrm{~h}$ at $37^{\circ} \mathrm{C}$. Viable cells were identified using the CCK-8 assay, which relies on the ability of mitochondrial dehydrogenases to oxidize WST-8 to a formazan product. The spectrophotometric absorbance at $450 \mathrm{~nm}$ was measured using a microplate reader (BioTek Instruments Inc., Winooski, VT, USA). The tests were performed in triplicate. 

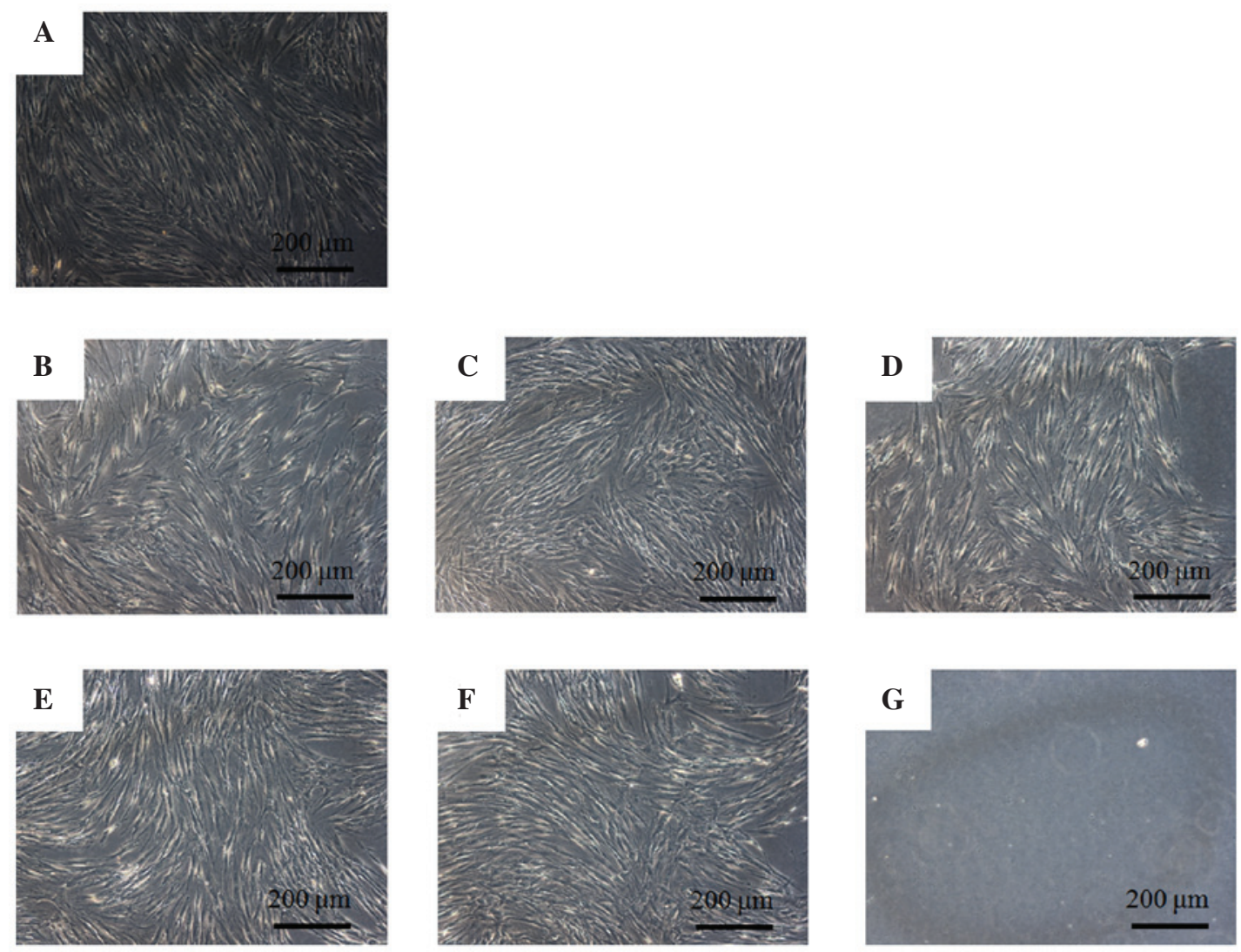

Figure 2. Cell morphology on day 3 using inverted microscopy following treatment with tacrolimus of different concentrations. (A) Control, (B) $0.001 \mu \mathrm{g} / \mathrm{ml}$ group, (C) $0.01 \mu \mathrm{g} / \mathrm{ml}$ group, (D) $0.1 \mu \mathrm{g} / \mathrm{ml}$ group, (E) $1 \mu \mathrm{g} / \mathrm{ml}$ group, (F) $10 \mu \mathrm{g} / \mathrm{ml}$ group and (G) $100 \mu \mathrm{g} / \mathrm{ml}$ group.
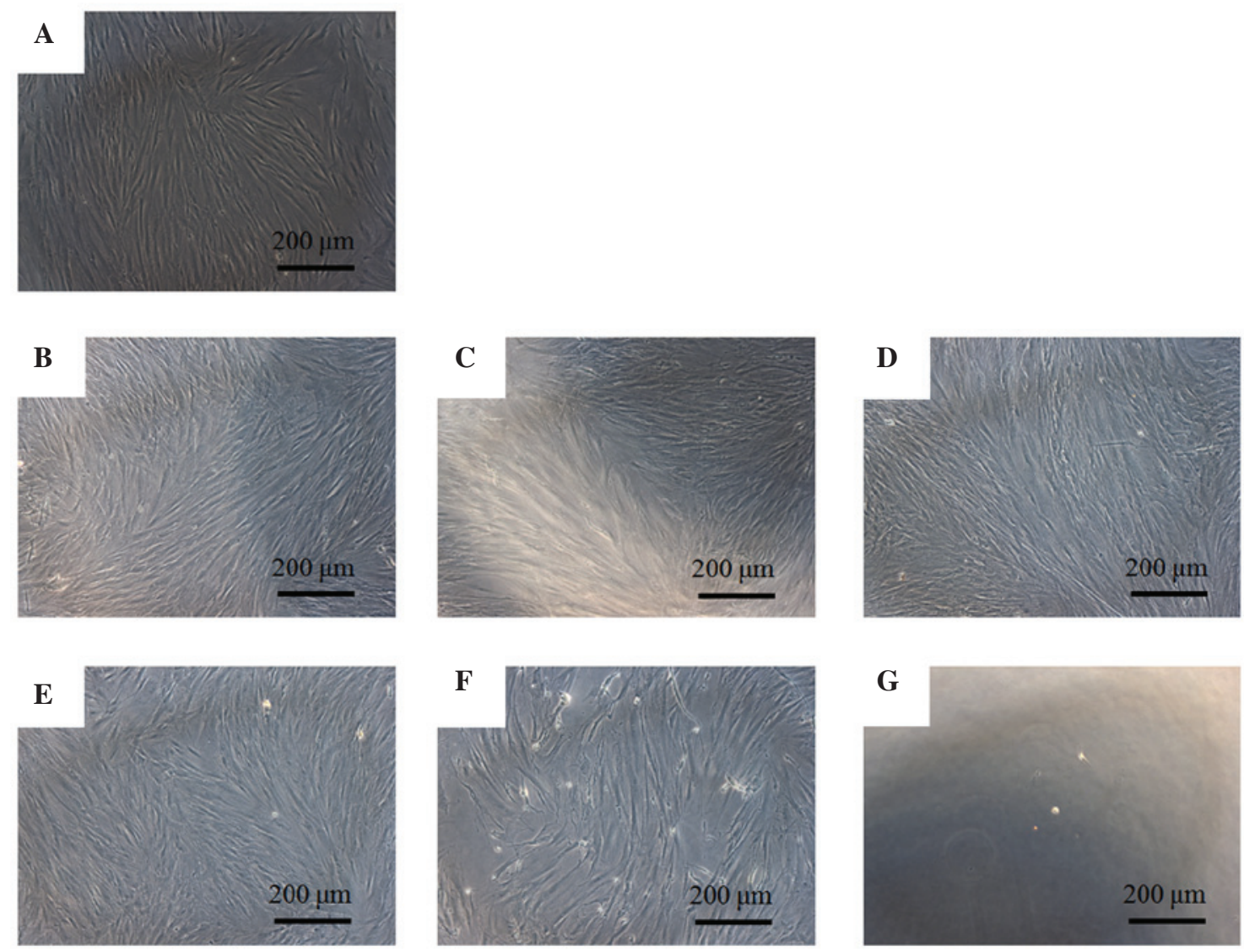

Figure 3. Cell morphology on day 5 using inverted microscopy following treatment with tacrolimus of different concentrations. (A) Control, (B) $0.001 \mu \mathrm{g} / \mathrm{ml}$ group, (C) $0.01 \mu \mathrm{g} / \mathrm{ml}$ group, (D) $0.1 \mu \mathrm{g} / \mathrm{ml}$ group, (E) $1 \mu \mathrm{g} / \mathrm{ml}$ group, (F) $10 \mu \mathrm{g} / \mathrm{ml}$ group, (G) $100 \mu \mathrm{g} / \mathrm{ml}$ group. 

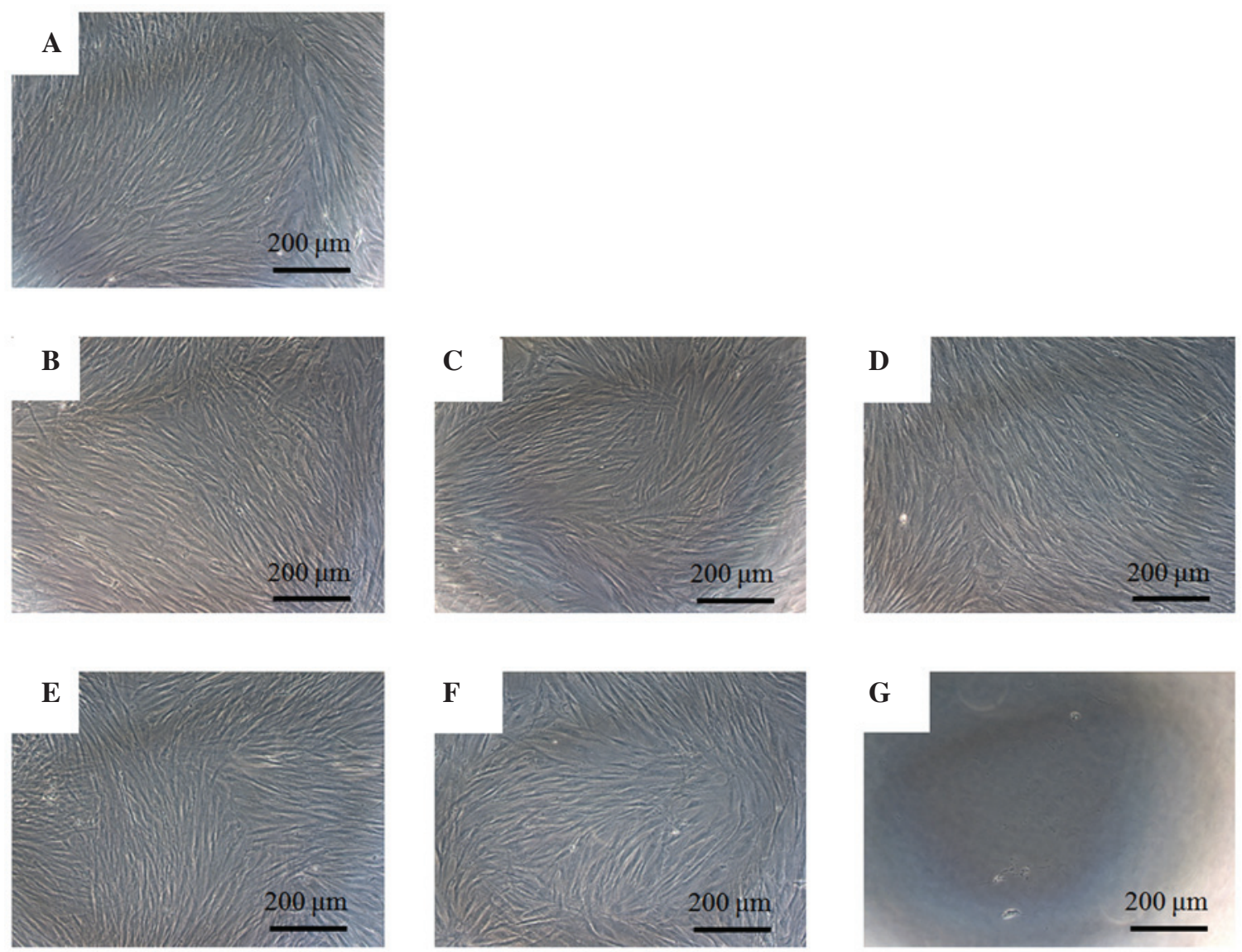

Figure 4. Cell morphology on day 7 using inverted microscopy following treatment with tacrolimus of different concentrations. (A) Control, (B) $0.001 \mu \mathrm{g} / \mathrm{ml}$ group, (C) $0.01 \mu \mathrm{g} / \mathrm{ml}$ group, (D) $0.1 \mu \mathrm{g} / \mathrm{ml}$ group, (E) $1 \mu \mathrm{g} / \mathrm{ml}$ group, (F) $10 \mu \mathrm{g} / \mathrm{ml}$ group and (G) $100 \mu \mathrm{g} / \mathrm{ml}$ group.

Alizarin Red S staining. Cell cultures obtained on days 5 and 7 were washed twice with PBS, fixed with $70 \%$ ethanol and rinsed twice with deionized water. Cultures were stained with Alizarin Red S (Wako Pure Chemical Industries, Ltd., Osaka, Japan) and evaluated with a microscope (Leica DM IRB; Leica Microsystems). To remove non-specifically bound stain, cultures were washed three times with deionized water and once with PBS for 15 min at ambient temperature. Bound dye was solubilized in $10 \mathrm{mM}$ sodium phosphate containing $10 \%$ cetylpyridinium chloride (Sigma-Aldrich) and quantified spectrophotometrically at $560 \mathrm{~nm}$ (PowerWave XS2; BioTek Instruments, Inc., Winooski, VT, USA).

Statistical analysis. The data are presented as the mean \pm standard deviation of the experiments. A one-way analysis of variance with post-hoc test was performed to determine the differences between the groups using a commercially available program (SPSS 12 for Windows, SPSS Inc., Chicago, IL, USA). P $<0.05$ was considered to indicate a statistically significant difference.

\section{Results}

Evaluation of cell morphology. The control group showed normal fibroblast morphology on day 1 (Fig. 1). The shapes of the cells treated with $0.001,0.01,0.1,1$ and $10 \mu \mathrm{g} / \mathrm{ml}$ tacrolimus were similar to those of the control group. However, the $100 \mu \mathrm{g} / \mathrm{ml}$ group was markedly different when compared with the control group. The shapes of the cells in the $100 \mu \mathrm{g} / \mathrm{ml}$ group were rounder, and fewer cells were present. The morphology of the cells on day 3 is shown in Fig. 2. An increased number of cells were observed in each group and the shapes of the cells in the tested groups were similar to those in the control group. The results for cells on days 5 and 7 are shown in Figs. 3 and 4, respectively. Noticeable differences were observed in the $100 \mu \mathrm{g} / \mathrm{ml}$ group.

Cellular viability. The CCK-8 results demonstrated cellular viability on days $1,3,5$ and 7 are shown in Fig. 5. All groups except the 10 and $100 \mu \mathrm{g} / \mathrm{ml}$ group showed relatively increased cell proliferation over time. The cultures grown in the presence of tacrolimus at $0.001,0.01,0.1,1$ and $10 \mu \mathrm{g} / \mathrm{ml}$ did not show any statistically significant differences compared with the control at days 1, 3 and 5 using the CCK- 8 assays $(\mathrm{P}>0.05)$. However, growth in the presence of tacrolimus at a concentration of $100 \mu \mathrm{g} / \mathrm{ml}$ resulted in decreases in the CCK-8 values at days 3,5 and $7(\mathrm{P}<0.05)$.

Mineralization assay. Mineralized extracellular deposits were minimally observed after Alizarin Red S staining on day 5 (Fig. 6). Increased mineralized deposits were noted on day 7 (Fig. 7). The quantitative results regarding bound dye on days 5 and 7 are shown in Fig. 8. The cultures grown in the presence of $0.001,0.01,0.1$ and $1 \mu \mathrm{g} / \mathrm{ml}$ tacrolimus exhibited increased mineralized deposits compared with the control on day 5 . The relative values of the mineralization at $0.001,0.01$, 


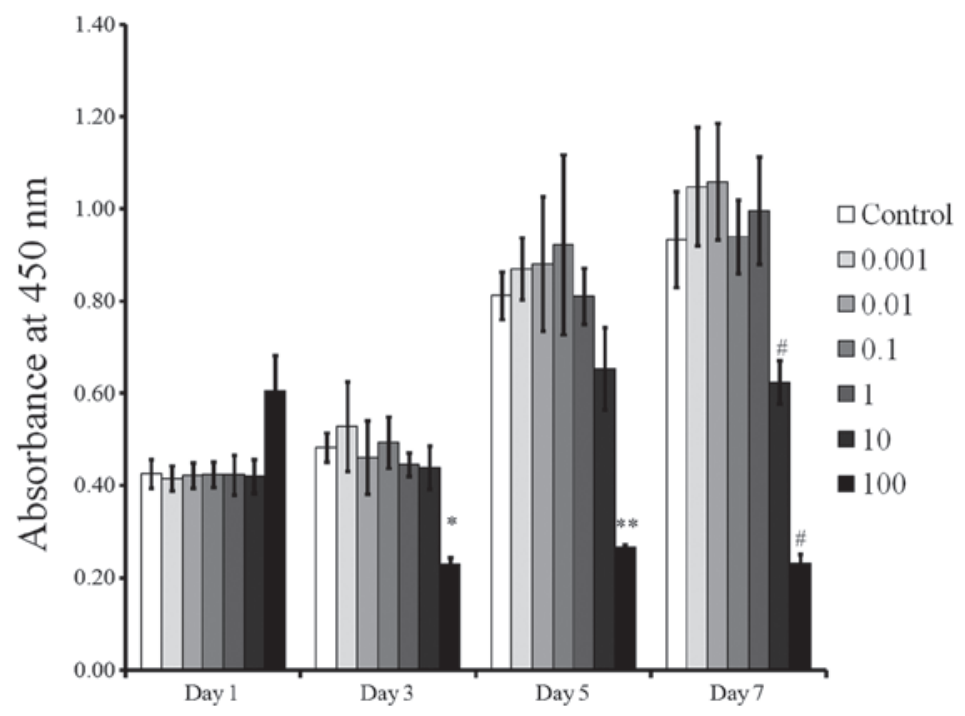

Figure 5. Cellular viability using cell counting kit-8 assay on days $1,3,5$ and 7 following treatment with different concentrations of tacrolimus. "P<0.05 compared with the control group at day $3 .{ }^{* *} \mathrm{P}<0.05$, compared with the control group at day $5 .{ }^{\sharp} \mathrm{P}<0.05$ compared with the control group at day 7 .
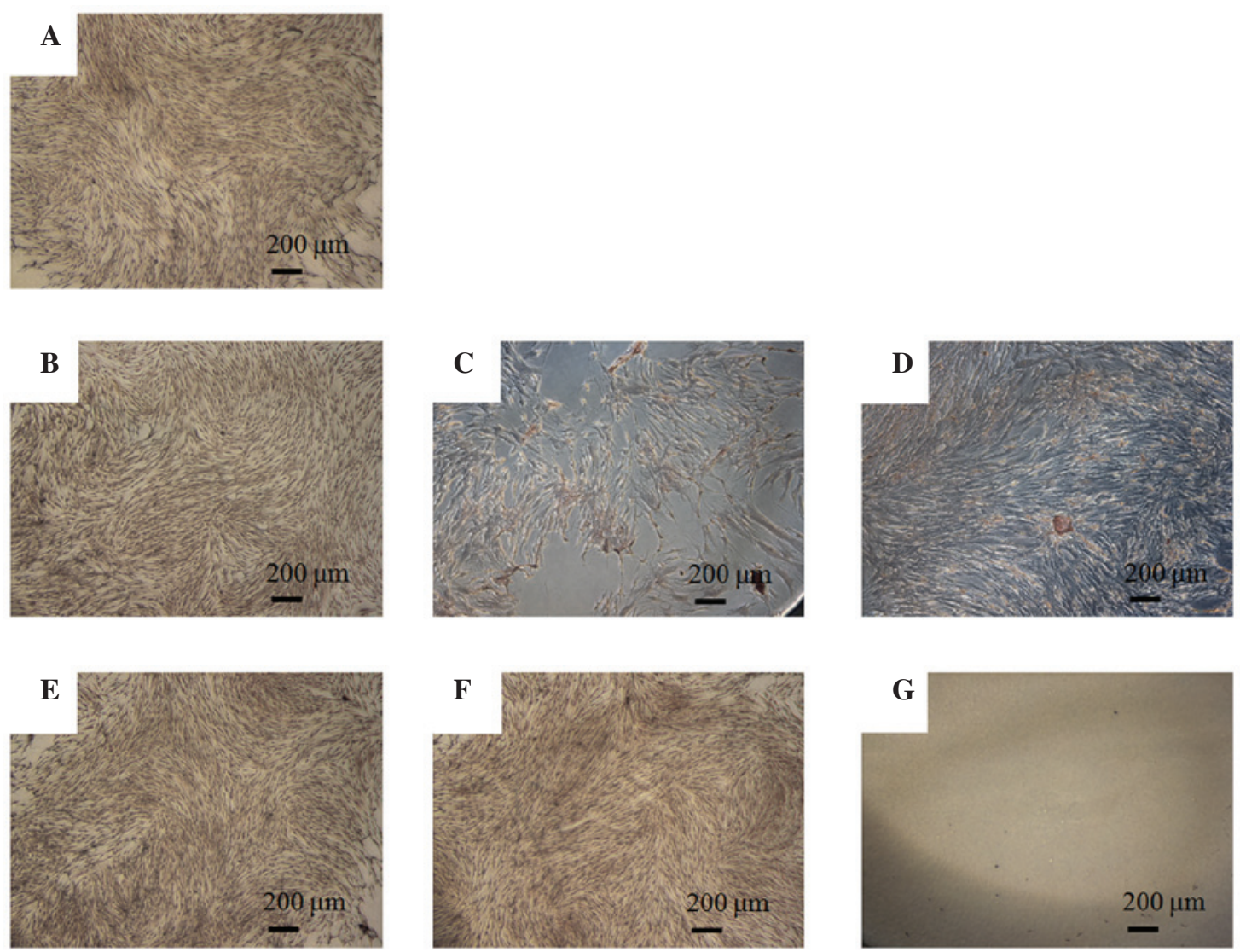

Figure 6. Results of Alizarin Red S staining on day 5 following treatment with different concentrations of tacrolimus. (A) Control, (B) $0.001 \mu \mathrm{g} / \mathrm{ml}$ group, (C) $0.01 \mu \mathrm{g} / \mathrm{ml}$ group, (D) $0.1 \mu \mathrm{g} / \mathrm{ml}$ group, (E) $1 \mu \mathrm{g} / \mathrm{ml}$ group, (F) $10 \mu \mathrm{g} / \mathrm{ml}$ group, (G) $100 \mu \mathrm{g} / \mathrm{ml}$ group.

0.1 and $1 \mu \mathrm{g} / \mathrm{ml}$ of tacrolimus were $110.9 \pm 10.7 \%, 102.1 \pm 8.4 \%$, $106.5 \pm 8.0 \%$, and $111.8 \pm 6.7 \%$, respectively when the result of the control group on day 5 was considered to be $100 \%$ $(100.0 \pm 9.1 \%)$. A significant decrease in mineralization was observed in the $100 \mu \mathrm{g} / \mathrm{ml}$ group on day 5 in comparison with the control group $(\mathrm{P}<0.05)$. The results for day 7 showed that treatment with tacrolimus at concentrations $0.001-1 \mu \mathrm{g} / \mathrm{ml}$ led to increase mineralized deposits compared with the control group. The relative value of the mineralization at $0.001,0.01$, 0.1 and $1 \mu \mathrm{g} / \mathrm{ml}$ of tacrolimus were $118.0 \pm 11.2,123.6 \pm 12.3$, $118.3 \pm 4.5$ and $104.4 \pm 5.9 \%$, respectively, when the result of the control group on day 7 was considered $100 \%(100.0 \pm 5.4 \%)$. A statistically significant decrease was observed in the $100 \mu \mathrm{g} / \mathrm{ml}$ group on day 7 in comparison with the control group $(\mathrm{P}<0.05)$. 

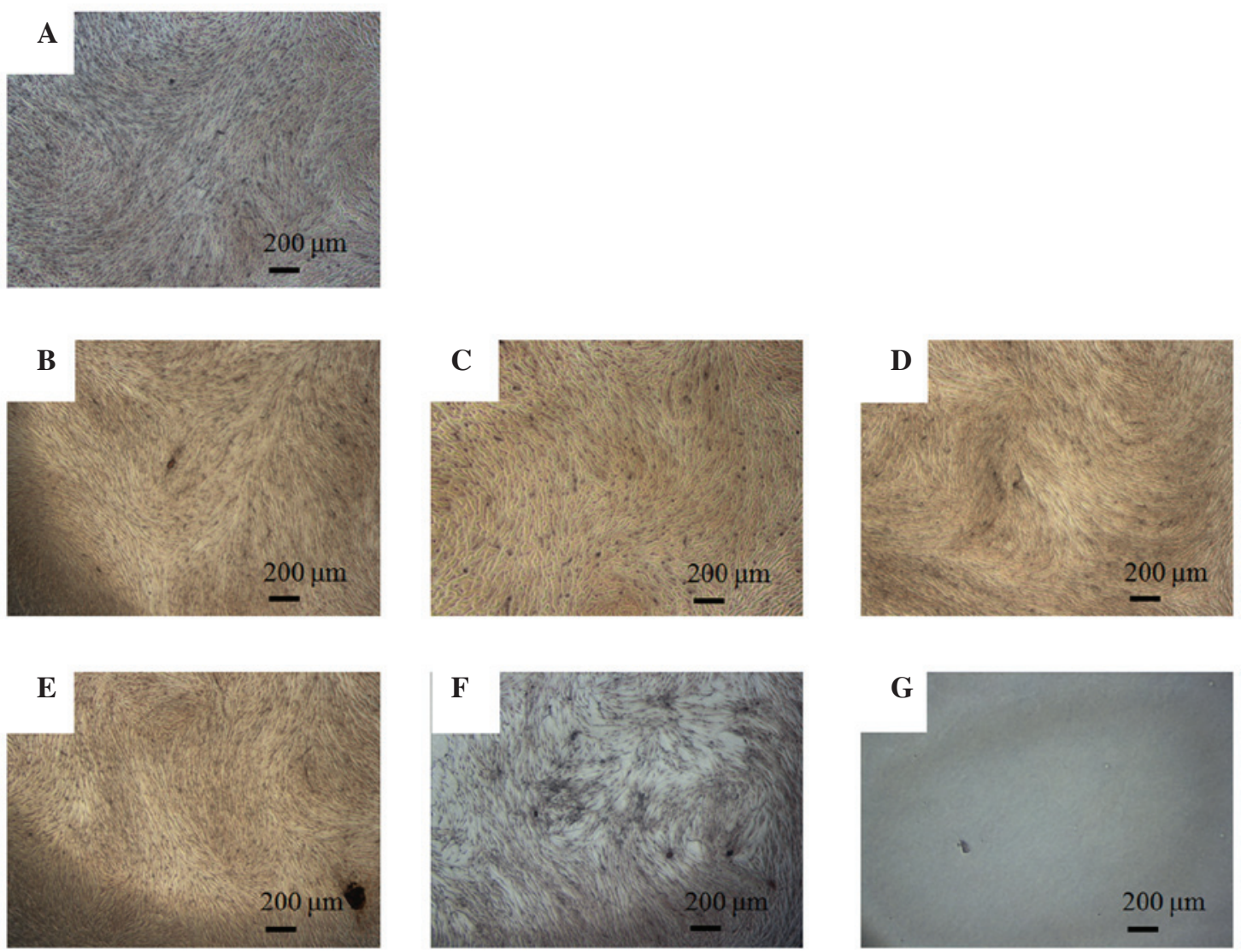

Figure 7. Results of Alizarin Red S staining on day 7 following treatment with different concentrations of tacrolimus. (A) Control, (B) $0.001 \mu \mathrm{g} / \mathrm{ml}$ group, (C) $0.01 \mu \mathrm{g} / \mathrm{ml}$ group, (D) $0.1 \mu \mathrm{g} / \mathrm{ml}$ group, (E) $1 \mu \mathrm{g} / \mathrm{ml}$ group, (F) $10 \mu \mathrm{g} / \mathrm{ml}$ group, (G) $100 \mu \mathrm{g} / \mathrm{ml}$ group.

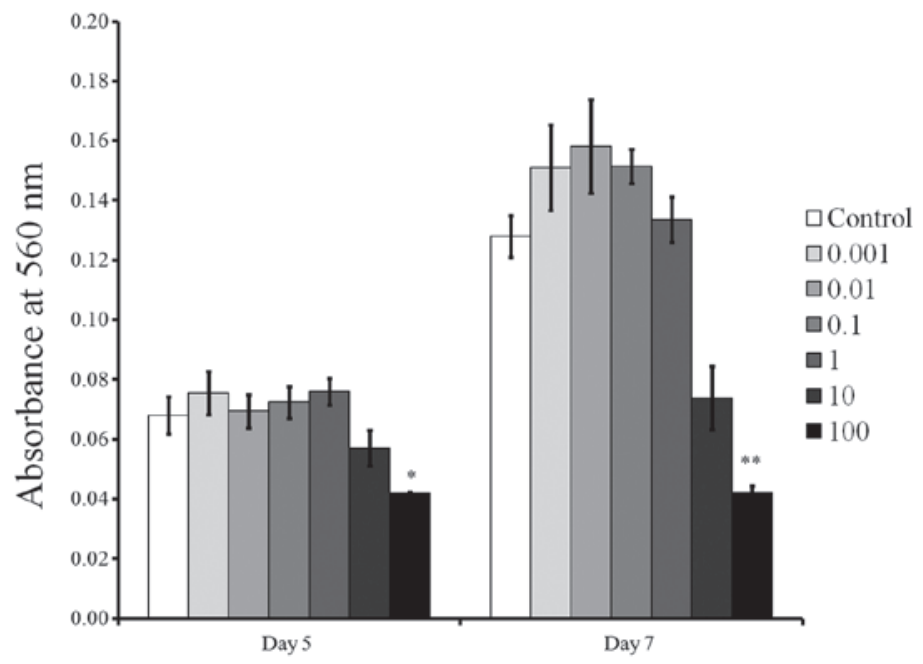

Figure 8. Quantitative results of mineralization assay on days 5 and $7 .{ }^{*} \mathrm{P}<0.05$ compared with the control group at day 5 . ${ }^{* *} \mathrm{P}<0.05$ compared with the control group at day 7 .

\section{Discussion}

Immunosuppressants have provided great improvement in organ transplantation by suppressing the rejection of allografts; this has increased the survival rate of organ transplant patients (23). Tacrolimus (FK506) is a widely-used, well-known immunosuppressant used following kidney or heart transplantation, and has been recognized as effective in promoting the growth of bone grafts (24). The present study was performed in order to investigate the effects of tacrolimus on proliferation and osteoblastic differentiation of mesenchymal stem cells in vitro.

This study determined the effects of tacrolimus on the morphology, cell viability and mineralization following treatment with $0.001-100 \mu \mathrm{g} / \mathrm{ml}$ tacrolimus. The cells exposed to tacrolimus at concentrations of $0.001-10 \mu \mathrm{g} / \mathrm{ml}$ exhibited 
a similar fibroblastic spindle shape. Short-term application of tacrolimus did not result in morphologic changes at final concentrations ranging from 0.001 to $10 \mu \mathrm{g} / \mathrm{ml}$.

Cellular viability was determined using a CCK-8 assay, which is based on mitochondrial enzyme reduction of the WST- 8 and spectrophotometric quantification of the water-soluble formazan dye generated (25). This study showed that tacrolimus at the tested concentrations was not identified to exhibit a significant effect on the viability of stem cells derived from the gingiva at final concentrations ranging from 0.001 to $10 \mu \mathrm{g} / \mathrm{ml}$. However, tacrolimus at $100 \mu \mathrm{g} / \mathrm{ml}$ decreased cell viability on days 3,5 and 7 .

Osteogenic differentiation can be evaluated by Alizarin red S staining (26). The presence of calcium in cellular deposits was confirmed by Alizarin Red S staining with cetylpyridinium chloride for quantification (27). Tacrolimus at 0.001, 0.01 and $1 \mu \mathrm{g} / \mathrm{ml}$ resulted in the highest degree of mineralized nodule formation on day 7. A previous study showed that tacrolimus at 0.04 and $0.4 \mu \mathrm{g} / \mathrm{ml}$ enhanced osteoblastic differentiation of rat mesenchymal stem cells (20). Co-stimulation with tacrolimus $(1.0 \mu \mathrm{g} / \mathrm{ml})$ and bone morphogenetic protein-9 $(100 \mathrm{ng} / \mathrm{ml})$ induced marked osteoblastic differentiation of dedifferentiated fat cells, which were isolated from mature adipocytes using the ceiling culture method and exhibit similar characteristics to mesenchymal stem cells (28). In the present study, the highest differentiation was achieved at $0.01 \mu \mathrm{g} / \mathrm{ml}$; however, a previous study demonstrated that remarkable osteoblast differentiation was achieved at $1.0 \mu \mathrm{g} / \mathrm{ml}(20)$. The differences may be explained by the different type and stage of the cells, the culturing time period and the culture system $(29,30)$.

A previous study demonstrated that tacrolimus promoted the early stage of osteoinduction (24). The mechanism underlying osteogenic differentiation has not yet been fully elucidated; however, it has been suggested that the osteogenic effect of tacrolimus may involve bone morphogenetic protein signaling (16). A previous report suggested that tacrolimus promoted osteogenic differentiation by activating BMP receptors through interacting with FK506-binding protein 12 (16). Tacrolimus enhanced the positive effects of bone morphogenetic proteins on alikaline phosphatase activity and osteocalcin in mRNA (19). The effects of the combination treatment with bone morphogenetic protein and tacrolimus acted in a dose- and time-dependent manner (19).

In conclusion, the present study demonstrated that treatment with tacrolimus at the tested concentrations ranging from 0.001 to $10 \mu \mathrm{g} / \mathrm{ml}$ did not result in significant changes in the viability of stem cells derived from gingiva, but increased osteogenic differentiation of the stem cells. Further studies related to this phenomenon in an in vivo model are necessary in order to ascertain greater understanding.

\section{Acknowledgements}

This study was supported by the 2015 Yeungnam University, Basic Science Research Program (grant nos. 2014R1A1A1002536 and 2015R1A2A2A04005616) and the Medical Research Center Program (grant no. 2015R1A5A2009124) through the National Research Foundation of Korea (NRF) funded by the Ministry of Science, ICT and Future Planning.

\section{References}

1. Beyer Nardi N and da Silva Meirelles L: Mesenchymal stem cells: Isolation, in vitro expansion and characterization. Handb Exp Pharmacol: 249-282, 2006.

2. Chen WC, Péault B and Huard J: Regenerative translation of human blood-vessel-derived MSC precursors. Stem Cells Int 2015: 375187, 2015.

3. Deng S, Huang R, Wang J, Zhang S, Chen Z, Wu S, Jiang Y, Peng Q, Cai X and Lin Y: Miscellaneous animal models accelerate the application of mesenchymal stem cells for cartilage regeneration. Curr Stem Cell Res Ther 9: 223-233, 2014.

4. Landa-Solís C, Granados-Montiel J, Olivos-Meza A, Ortega-Sánchez C, Cruz-Lemini M, Hernández-Flores C, Chang-González ME, García RG, Olivos-Díaz B, Velasquillo-Martínez MC et al: Cryopreserved CD90+ cells obtained from mobilized peripheral blood in sheep: a new source of mesenchymal stem cells for preclinical applications. Cell Tissue Bank: July 29, 2015 (Epub ahead of print).

5. Caplan AI: Adult mesenchymal stem cells for tissue engineering versus regenerative medicine. J Cell Physiol 213: 341-347, 2007.

6. Lee SI, Yeo SI, Kim BB, Ko Y and Park JB: Formation of size-controllable spheroids using gingiva-derived stem cells and concave microwells: Morphology and viability tests. Biomed Rep 4: 97-101, 2016.

7. Jeong SH, Lee JE, Kim BB, Ko Y and Park JB: Evaluation of the effects of Cimicifugae Rhizoma on the morphology and viability of mesenchymal stem cells. Exp Ther Med 10: 629-634, 2015.

8. Tamura S, Ohike A, Ibuki R, Amidon GL and Yamashita S: Tacrolimus is a class II low-solubility high-permeability drug: The effect of P-glycoprotein efflux on regional permeability of tacrolimus in rats. J Pharm Sci 91: 719-729, 2002.

9. Scholten EM, Cremers SC, Schoemaker RC, Rowshani AT, van Kan EJ, den Hartigh J, Paul LC and de Fijter JW: AUC-guided dosing of tacrolimus prevents progressive systemic overexposure in renal transplant recipients. Kidney Int 67: 2440-2447, 2005.

10. Felipe CR, Garcia C, Moreira S, Olsen N, Silva HT and Pestana OM: Choosing the right dose of new immunossuppressive drugs for new populations: Importance of pharmacokinetic studies. Transplant Proc 33: 1095-1096, 2001.

11. van Hooff JP, Boots JM, van Duijnhoven EM and Christiaans MH: Dosing and management guidelines for tacrolimus in renal transplant patients. Transplant Proc 31: 54S-57S, 1999.

12. Taylor DO, Barr ML, Radovancevic B, Renlund DG, Mentzer RM Jr, Smart FW, Tolman DE, Frazier OH, Young JB and VanVeldhuisen P: A randomized, multicenter comparison of tacrolimus and cyclosporine immunosuppressive regimens in cardiac transplantation: Decreased hyperlipidemia and hypertension with tacrolimus. J Heart Lung Transplant 18: 336-345, 1999.

13. Busuttil RW, Klintmalm GB, Lake JR, Miller CM and Porayko M: General guidelines for the use of tacrolimus in adult liver transplant patients. Transplantation 61: 845-847, 1996.

14. Staatz CE and Tett SE: Clinical pharmacokinetics and pharmacodynamics of tacrolimus in solid organ transplantation. Clin Pharmacokinet 43: 623-653, 2004.

15. Laskow DA, Neylan JF III, Shapiro RS, Pirsch JD, Vergne-Marini PJ and Tomlanovich SJ: The role of tacrolimus in adult kidney transplantation: A review. Clin Transplant 12: 489-503, 1998

16. Kugimiya F, Yano F, Ohba S, Igawa K, Nakamura K, Kawaguchi H and Chung UI: Mechanism of osteogenic induction by FK506 via BMP/Smad pathways. Biochem Biophys Res Commun 338: 872-879, 2005.

17. Park KM, Hay JE, Lee SG, Lee YJ, Wiesner RH, Porayko MK and Krom RA: Bone loss after orthotopic liver transplantation: FK 506 versus cyclosporine. Transplant Proc 28: 1738-1740, 1996.

18. Stempfle HU, Werner C, Echtler S, Assum T, Meiser B, Angermann CE, Theisen K and Gärtner R: Rapid trabecular bone loss after cardiac transplantation using FK506 (tacrolimus)-based immunosuppression. Transplant Proc 30: 1132-1133, 1998.

19. Tang L, Ebara S, Kawasaki S, Wakabayashi S, Nikaido T and Takaoka K: FK506 enhanced osteoblastic differentiation in mesenchymal cells. Cell Biol Int 26: 75-84, 2002.

20. Byun YK, Kim KH, Kim SH, Kim YS, Koo KT, Kim TI, Seol YJ, $\mathrm{Ku}$ Y, Rhyu IC and Lee YM: Effects of immunosuppressants, FK506 and cyclosporin A, on the osteogenic differentiation of rat mesenchymal stem cells. J Periodontal Implant Sci 42: 73-80, 2012. 
21. Hoogduijn MJ, Crop MJ, Korevaar SS, Peeters AM, Eijken M, Maat LP, Balk AH, Weimar W and Baan CC: Susceptibility of human mesenchymal stem cells to tacrolimus, mycophenolic acid and rapamycin. Transplantation 86: 1283-1291, 2008.

22. Jin SH, Lee JE, Yun JH, Kim I, Ko Y and Park JB: Isolation and characterization of human mesenchymal stem cells from gingival connective tissue. J Periodontal Res 50: 461-467, 2015.

23. Lechler RI, Sykes M, Thomson AW and Turka LA: Organ transplantation - how much of the promise has been realized? Nat Med 11: 605-613, 2005.

24. Kaihara S, Bessho K, Okubo Y, Sonobe J, Kusumoto K, Ogawa Y and Iizuka T: Effect of FK506 on osteoinduction by recombinant human bone morphogenetic protein-2. Life Sci 72: 247-256, 2002.

25. Utheim TP, Raeder S, Utheim ØA, Cai Y, Roald B, Drolsum L, Lyberg T and Nicolaissen B: A novel method for preserving cultured limbal epithelial cells. Br J Ophthalmol 91: 797-800, 2007.
26. Bang SM, Moon HJ, Kwon YD, Yoo JY, Pae A and Kwon IK: Osteoblastic and osteoclastic differentiation on SLA and hydrophilic modified SLA titanium surfaces. Clin Oral Implants Res 25 831-837, 2014

27. Wang B, Bi M, Zhu Z, Wu L and Wang J: Effects of the antihypertensive drug benidipine on osteoblast function in vitro. Exp Ther Med 7: 649-653, 2014.

28. Nakamura T, Shinohara Y, Momozaki S, Yoshimoto T and Noguchi K: Co-stimulation with bone morphogenetic protein-9 and FK506 induces remarkable osteoblastic differentiation in rat dedifferentiated fat cells. Biochem Biophys Res Commun 440: 289-294, 2013.

29. Quarles LD, Yohay DA, Lever LW, Caton R and Wenstrup RJ: Distinct proliferative and differentiated stages of murine MC3T3-E1 cells in culture: An in vitro model of osteoblast development. J Bone Miner Res 7: 683-692, 1992.

30. Park JB, Zhang H, Lin CY, Chung CP, Byun Y, Park YS and Yang VC: Simvastatin maintains osteoblastic viability while promoting differentiation by partially regulating the expressions of estrogen receptors $\alpha$. J Surg Res 174: 278-283, 2012. 